I must repeat again, what I have said before, that if it is decided to tell a hospital patient the truth in the absence of the family doctor, or if the patient inadvertently gets to know the diagnosis, the family doctor should be told before the patient is discharged from hospital. In all conscience, his task will be difficult enough from then onwards, but to be placed in the position of having to make a first visit to a patient at home and to find that both the patient and his relatives know more of the diagnosis than he does is, to say the least of it, humiliating to the family doctor and can, indeed, be most confusing.

Similarly, the family doctor should be made aware of the fact that a patient has been discharged from hospital without being told the truth; and the final comment I have to make here is that it is unfair on a sister, a nurse, or a junior resident for them to be left to tell the patient-or even his relatives. The understandable lack of experience on the part of a young doctor or nurse, together with an equally understandable lack of knowledge of the patient and his home background, make it unjustifiable for them to be left to bear the burden of the crisis ; moreover, such an occasion should surely call for the presence of the senior doctor. On the face of it, this is the least he can do for his patient.

\section{Conclusion}

I cannot complete what I have to say on management without commenting on what a tremendous advantage it is for a family doctor to have a district nurse and health visitor attached to him and caring only for the patients of his practice. These three can work together in the team, each playing his particular part in the management of the illness, taking as much as possible of the burden of care from the relatives, sharing in the anxieties, helping with problems, and comforting the sick.

Other helpers, such as home helps, the Red Cross (with night care), the churches, W.V.S. meals on wheels, and many othersall have a part to play. Even neighbours may have to be drawn in, and one must not forget the Marie Curie nurses.

With all the above, I believe that the key figure in the management of a patient with malignant disease must always be the general practitioner, and I believe this because I also believe that it should be exceptional for a patient in the final phases of his illness to be cared for anywhere else than in his own home. I know that on many occasions this is not possible-because of inadequate or difficult home conditions and occasionally because even the most devoted family will break down under the strain and the G.P. will then have to advise them to allow admission to a hospital or nursing-home-but, I repeat, wherever and whenever possible the patient should be at home throughout the final stages of his illness.

This, then, is all I can say in the time available to me, of the impact of malignant disease on the family doctor. It is perhaps a sad story ; certainly it can be an exciting one. The G.P.'s role is responsible and difficult-he has to be part doctor, part priest, part social worker, and part friend. His management may lead him into sorry truths, forgivable lies, regrettable mistakes, unhappy failures, and unexpected successes. All these form part of his job. Each case adds to his experience.

Hippocrates-perhaps-would not have had it otherwise.

\title{
Rejection Processes in Human Homotransplanted Kidneys
}

\author{
W. J. DEMPSTER,* F.R.C.S. ; C. V. HARRISON, $†$ M.D. ; R. SHACKMAN,* F.R.C.S.
}

[With Special Plate]

Brit. med. F., 1964, 2, 969-976

Few human homotransplanted kidneys have survived more than one year (Küss et al., 1962, 1963 ; Hamburger et al., 1962 ; Murray et al., 1963 ; Merrill et al., 1963 ; Shackman et al., 1963 ; Woodruff et al., 1963). Two transplants between dizygotic twins have survived several years (Merrill et al., 1960, 1963 ; Hamburger et al., 1959, 1963). The longest survival of a true homotransplanted kidney is now more than three years (Shackman et al., 1963). It is difficult to establish what factors are involved in long-term survival. Blood-group and leucocyteantigen compatibility may have some influence but they do not forecast how long any kidney will survive homotransplantation. While it is true that the best results so far recorded-the two dizygotic twins and our own case-involved close genetic relationships between donors and recipients, in the case of other long-term survivals the involved kidneys were obtained from unrelated donors (Merrill et al., 1963 ; Küss et al., 1963).

We are not only ignorant about the exact relation of the gene to prolonged survival but also about its relation to the rejection process. In the human it would appear that a homotransplanted kidney can, in conditions where no host modification had been attempted, be rejected in two ways-either by a

\footnotetext{
* Department of Surgery, Postgraduate Medical School of London,

Hammersmith.
t Department of Pathology, Postgraduate Medical School of London,
Hammersmith.
}

massive cellular infiltration (Michon et al., 1953) or by a vascular obliteration with minimal cellular infiltration (Hume et al., 1955). Recent reports indicate that striking vascular lesions may develop in homotransplanted kidneys in humans modified by either total body $x$-irradiation or cytotoxic drugs (Porter et al., 1963 ; Goodwin et al., 1963 ; Nemeth et al., 1963).

Our series of 13 consecutive human kidney homotransplants contains seven cases which can be grouped together on the basis of a common vascular lesion precipitating renal failure. The present paper describes these particular cases and attempts to unify both the cellular and the vascular types of rejection into one pathological process. The cases are presented in the order of duration of survival of the homotransplanted kidneys in order to illustrate the probable sequence and variety of vascular changes (Tables I and II).

\section{Case 1}

J. F., a man aged 41, had chronic pyelonephritis.

History.-When admitted to Hammersmith Hospital in December 1962 he gave a long history of renal failure and had required haemodialysis on four occasions. His general condition was poor, he was anaemic ( $\mathrm{Hb} 5.2 \mathrm{~g} . / 100 \mathrm{ml}$.) and hypertensive $(200 / 150 \mathrm{~mm}$. $\mathrm{Hg}$ ), and there was gross infection with Staphylococcus aureus. The 
infection was eventually controlled by antibiotics, but he developed congestive cardiac failure and pericarditis. He required repeated haemodialysis and transfusions, but after considerable vacillation was thought fit enough to undergo renal homotransplantation. Just before the transplantation he developed a Pseudomonas pyocyanea pharyngotracheitis, which fortunately was controlled by broadspectrum antibiotics.

Method Used to Suppress Rejection.-Intravenous Endoxan (cyclophosphamide) (100 mg./day) and hydrocortisone (100 mg./ day) were given: local $x$-irradiation (200 rads) to the kidney was also given on the day after operation.

Operation (25 February 1963).- The donor of the fresh kidney was a younger brother aged 39. The kidney was placed in the left iliac fossa because the right femoral vessels had been used for haemodialysis. Urine was excreted immediately. The period of ischaemia was 50 minutes.

Post-operative Course.-Five litres of urine were produced in the first 24 hours. The patient soon began to feel better and his generalized oedema rapidly resolved. The kidney functioned well for five days, and the blood urea, which had been $350 \mathrm{mg} . / 100 \mathrm{ml}$. on the day of operation, fell to $150 \mathrm{mg}$. by the sixth day. Then there was a dramatic deterioration of renal function, the generalized oedema recurred, and he died on the ninth post-operative day. Fever (axillary temperature $100-102^{\circ} \mathrm{F}$. ; $37.8-38.9^{\circ} \mathrm{C}$.) had been present from the day of the operation.

\section{Post-mortem Examination}

Necropsy Findings.-Death was due to uraemia. The vascular anastomoses were healthy and there was no infection.

Homotransplanted Kidney.-Vasculature: No change was detected in the main renal artery. There was a plasma-cell and a lymphocyte infiltration of the arcuate and interlobular arteries, and in some of these vessels there was necrosis of a few muscle cells (Special Plate, Fig. 1). The cellular infiltration extended to arterioles and to interlobar arteries, but it was slight and not associated with necrosis. Glomeruli: There was some swelling and thickening of the endothelium and epithelium of some glomeruli, particularly the most distal. Tubules: Damage was variable and patchy ; the subcapsular zone was the most advanced. Liquefaction of the tubules was progressing and infiltrating cells were very obvious. Interstitial tissue: Severe and widespread oedema was present. There was a marked infiltration by cells varying from fibroblastic type to immature plasma cells.

Summary.-The histological features were those characteristic of cellular rejection, but the cellular infiltration and muscle necrosis of the vessels also indicated a vascular rejection.

\section{Case 2}

P. D., a man aged 38 (Case 2 in the paper by Shackman et al., 1963), had progressive subacute glomerulonephritis.

History.-After an attack of acute nephritis in January 1961, clinical and histological evidence of irrecoverable renal failure led to the decision to advise renal homotransplantation.,

Method Used to Suppress Rejection.-He was given total body $x$-irradiation (100 rads) before operation and local $x$-irradiation (200 rads) to the kidney after operation on the 5 th, 16 th, and 21 st days. Hydrocortisone (100 mg./day) was also given.

Operation (5 March 1961). - The donor of the fresh kidney was an unrelated woman aged 48 years. The patient's own kidneys were removed prior to the operation. The kidney was placed in the right iliac fossa. Urine was excreted immediately. The period of ischaemia was 45 minutes.

Post-operative Course.-A good diuresis occurred during the first two days and the blood urea fell steadily for four days but then

TABLE I.-Blood Groups of Recipients and Donors

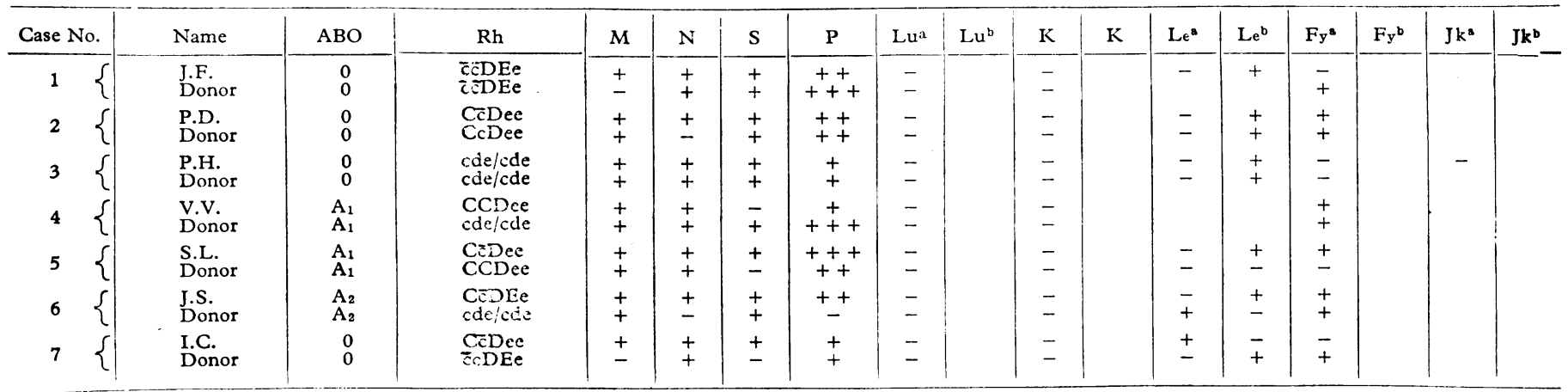

TABLE II.-Vascular Lesions in Seven Cases of Homotransplanted Kidneys

\begin{tabular}{|c|c|c|c|c|c|c|c|c|c|c|c|c|}
\hline $\begin{array}{l}\text { Case } \\
\text { No. }\end{array}$ & Name & $\begin{array}{l}\text { Original } \\
\text { Disease }\end{array}$ & $\begin{array}{l}\text { Period of } \\
\text { Good } \\
\text { Function }\end{array}$ & $\begin{array}{l}\text { Subsequent } \\
\text { Function }\end{array}$ & $\begin{array}{c}\text { Pyrexia } \\
\text { After } \\
\text { Operation }\end{array}$ & $\begin{array}{l}\text { Hyper- } \\
\text { tension } \\
\text { Present }\end{array}$ & $\begin{array}{l}\text { Severity } \\
\text { of } \\
\text { Vascular } \\
\text { Lesion }\end{array}$ & $\begin{array}{l}\text { Severity of } \\
\text { Glomerular } \\
\text { Involvement }\end{array}$ & $\begin{array}{l}\text { Cell } \\
\text { Infiltra- } \\
\text { tion of } \\
\text { Vessel } \\
\text { Wall }\end{array}$ & $\begin{array}{l}\text { Inter- } \\
\text { stitial } \\
\text { Infiltra- } \\
\text { tion }\end{array}$ & $\begin{array}{l}\text { Relation- } \\
\text { ship to } \\
\text { Donor }\end{array}$ & $\begin{array}{c}\text { Method of } \\
\text { Suppressing } \\
\text { Immune Reaction }\end{array}$ \\
\hline 1 & J.F. & $\begin{array}{l}\text { Chronic } \\
\text { glomerular } \\
\text { nephritis }\end{array}$ & 6 days & $\begin{array}{l}\text { Sudden onset } \\
\text { of oliguria, } \\
\text { then anuria }\end{array}$ & + & + & + & $\begin{array}{l}15 \% \text { show } \\
\text { swelling of } \\
\text { endothelium }\end{array}$ & +++ & +++ & Related & Endoxan \\
\hline 2 & P.D. & $\begin{array}{l}\text { Subacute } \\
\text { glomerular } \\
\text { nephritis }\end{array}$ & 4 days & $\begin{array}{l}20 \text { days of } \\
\text { moderate } \\
\text { function }\end{array}$ & + & + & ++ & $\begin{array}{l}25 \% \text { grossly } \\
\text { dilated with or } \\
\text { without } \\
\text { thrombosis }\end{array}$ & ++ & ++ & Unrelated & $\begin{array}{l}\text { Total body } x \text {-irra- } \\
\text { diation }+ \text { local } \\
\text { irradiation to } \\
\text { kidney }\end{array}$ \\
\hline 3 & P.H. & $\begin{array}{l}\text { Chronic } \\
\text { pyelonephritis }\end{array}$ & $\begin{array}{l}0 \text { days. } \\
\text { Cadaver } \\
\text { kidney } \\
\text { anuric } \\
\text { for first } \\
8 \text { days }\end{array}$ & $\begin{array}{l}16 \text { days of } \\
\text { moderate } \\
\text { function, } \\
\text { then anuria }\end{array}$ & ++ & - & ++++ & $\begin{array}{l}90 \% \text { focal } \\
\text { infarcts and } \\
\text { paralytic } \\
\text { dilatation }\end{array}$ & ++ & minimal & Unrelated & $\underset{\text { mycin } C}{\text { Imuran }}+$ actino- \\
\hline 4 & V.V. & $\begin{array}{l}\text { Reflux chronic } \\
\text { pyelonephritis }\end{array}$ & $\begin{array}{l}0 \text { days. } \\
\text { Cadaver } \\
\text { kidney } \\
\text { anuric }\end{array}$ & Anuric & + & + & ++ & $\begin{array}{l}40 \% \text { fibrosed. } \\
37 \% \text { collapsed }\end{array}$ & ++ & minimal & Unrelated & $\begin{array}{l}\text { Splenectomy. } \\
\text { Imuran }+ \text { actino- } \\
\text { mycin C }\end{array}$ \\
\hline 5 & S.L. & $\begin{array}{l}\text { Chronic } \\
\text { pyelonephritis }\end{array}$ & 25 days & $\begin{array}{l}27 \text { days of moder- } \\
\text { ate function, } \\
\text { then anuria }\end{array}$ & + & + & + & Not assessable & - & - & Related & $\begin{array}{l}\text { Total body } x \text {-irra- } \\
\text { diation }+ \text { local } \\
x \text {-irradiation to } \\
\text { kidney }\end{array}$ \\
\hline 6 & J.S. & $\begin{array}{l}\text { Chronic } \\
\text { pyelonephritis }\end{array}$ & 12 days & $\begin{array}{l}\text { Gradual } \\
\text { deterioration }\end{array}$ & ++ & + & +++ & Not assessable & - & - & Unrelated & $\begin{array}{l}\text { Local } x \text {-irradiation } \\
\text { to kidney }\end{array}$ \\
\hline 7 & I.C. & $\begin{array}{l}\text { Calculous } \\
\text { pyelonephritis }\end{array}$ & 3 months & $\begin{array}{l}\text { Sharp decline to } \\
\text { poor function. } \\
\text { Oliguric } \\
6 \text { weeks. }\end{array}$ & - & + & +++ & $\begin{array}{l}49 \% \text { show } \\
\text { basement } \\
\text { membrane } \\
\text { thickening }\end{array}$ & ++ & Minimal & Unrelated & $\begin{array}{l}\text { Total body } x \text {-irra- } \\
\text { diation t local } \\
x \text {-irradiation to } \\
\text { kidney }\end{array}$ \\
\hline
\end{tabular}


started to rise slowly as the daily urine output declined and the creatinine clearance fell from 30 to $6 \mathrm{ml} . / \mathrm{min}$. The blood-pressure, which was $160 / 115 \mathrm{~mm}$. $\mathrm{Hg}$ before the operation, showed no significant sustained change. Slight fever followed the operation and continued for a week: it recurred again 10 days later. The patient meanwhile was feeling reasonably well. During the second week the urine output was more than $2 \mathrm{l}$./day and contained at least $5 \mathrm{~g}$. of urea per litre. A sudden decline in platelets developed three weeks after the operation, and two days later the count was $23,000 / \mathrm{cm}$. A masive internal haemorrhage was followed by death on the 25 th post-operative day.

\section{Post-mortem Examination}

Necropsy Findings.-Death was due to massive pulmonary haemorrhage following thrombocytopenia. The vascular anastomoses were healthy and there was no infection.

Homotransplanted Kidney.-Vasculature: The interlobular arteries were most severely affected but lesions were seen at all levels. The lesion consisted of necrosis of the media, with or without thrombosis, and sometimes with a loose cellular intimal proliferation. Cellular infiltration was like that in Case 1 but was not striking. Three-quarters of the interlobular arteries were affected. A few veins were thrombosed but necrosis could not be detected in any of them. Glomeruli and tubules: There were some necrosed glomeruli associated with necrosis of their afferent arterioles. Odd groups of tubules were necrotic and surrounded by haemorrhage. Interstitial tissue: There was much oedema and some fibrous thickening. Terminal haemorrhage was extensive and it was difficult to assess cellular infiltration.

Summary.-The vascular damage was interpreted as a form of rejection. It was widespread enough to account for renal failure.

\section{Case 3}

P. H., a boy aged 14, suffered from chronic pyelonephritis.

History.-In 1951 at the age of 2 years he was admitted to hospital with oedema and hypertension $(126 / 90 \mathrm{~mm}$. $\mathrm{Hg}$ ) and a diagnosis of nephrosis was made. He was treated by a low-salt and low-protein diet and repeated courses of A.C.T.H., but required readmission to hospital on several occasions between 1953 and 1960 . By 1960 the blood urea was $180 \mathrm{mg} . / 100 \mathrm{ml}$. In 1963 renal function declined rapidly and haemodialysis was required on two occasions.

Method Used to Suppress Rejection.-Actinomycin C (100 $\mu \mathrm{g} . /$ day) and Imuran (azathioprine) (100 mg./day) were started during the operation. Hydrocortisone (100 mg./day) was also given.

Operation (30 March 1963).-The donor kidney (cadaver) was obtained from a woman aged 55 who had died suddenly from a subarachnoid haemorrhage. It was removed and placed in a refrigerator at $4^{\circ} \mathrm{C}$. within 45 minutes of death and was subsequently transplanted approximately five hours after its removal. The kidney was placed in the right iliac fossa. The vascular anastomoses took 45 minutes.

Post-operative Course.-The kidney remained anuric for seven days and haemodialysis was required before it began to excrete urine on the eighth day (Fig. I). During the succeeding two weeks approximately $2 \mathrm{l}$./day (containing up to $6 \mathrm{~g}$. of urea per litre) were produced. A mild fever was present during the second week, but on the 20 th day the temperature reached $103.5^{\circ} \mathrm{F}$. $\left(39.7^{\circ} \mathrm{C}\right.$.) and Ps. pyocyanea was recovered from the blood-stream. Actinomycin $\mathrm{C}$ was stopped and polymyxin was given. Three days later jaundice and melaena were noted and Imuran was stopped. The urine output decreased, the white-blood cells and platelets suddenly declined; platelet transfusions were given but death occurred on the 26th day. Judged by the urine urea concentrations, the function of the kidney resembled that of a kidney in the early recovery phase of acute tubular necrosis. On the first day of collection the urine urea concentration was $240 \mathrm{mg} . / 100 \mathrm{ml}$; t three days later it was $400 \mathrm{mg}$. but the concentration never exceeded $600 \mathrm{mg}$. The total white-blood-cell and lymphocyte counts showed significant elevations on the sixth day and by the 13th day the total count had risen to 23,000 and the lymphocytes to 3,000. Both then began to fall, and on the 22 nd day the total count was only 400 , of which 200 were lymphocytes.

\section{Post-mortem Examination}

Necropsy Findings.-Apart from uraemia there was marrow aplasia and Ps. pyocyanea infection, with abscesses in the transplant. The vascular anastomoses were healthy.

Homotransplanted Kidney.-Vasculature : Lesions were seen in the arcuate and interlobular arteries and in the arterioles, but were maximal in the distal interlobular vessels, where $93 \%$ were affected. In the latter arteries there were cellular infiltration, medial necrosis, extensive thrombosis, and loose fibrous intimal thickening (Special Plate, Fig. 2). In the arcuate arteries cellular infiltration was slight; a medial necrosis and intimal thickening were present in a few but thrombosis was not seen. Most of the arterioles were necrotic and thrombosed. Glomeruli : Some were healthy, but many showed necrosis usually continuous with necrotic arterioles. Tubules: There was considerable infarction, mainly in the outer cortex. Interstitial tissue: The tissue was oedematous. There was a scanty cell infiltration, largely confined to perivenous zones.

Summary.-There was severe arterial disease maximal in the distal interlobular arteries and spreading backwards to arcuates and distally to glomerular loops. The tubular damage could be accounted for by ischaemia.

\section{Case 4}

V. V., a girl aged 19, had reflux chronic pyelonephritis.

History.-At the age of 5 years she began to have attacks of bronchial asthma. At the age of 18 she began to notice deteriora-
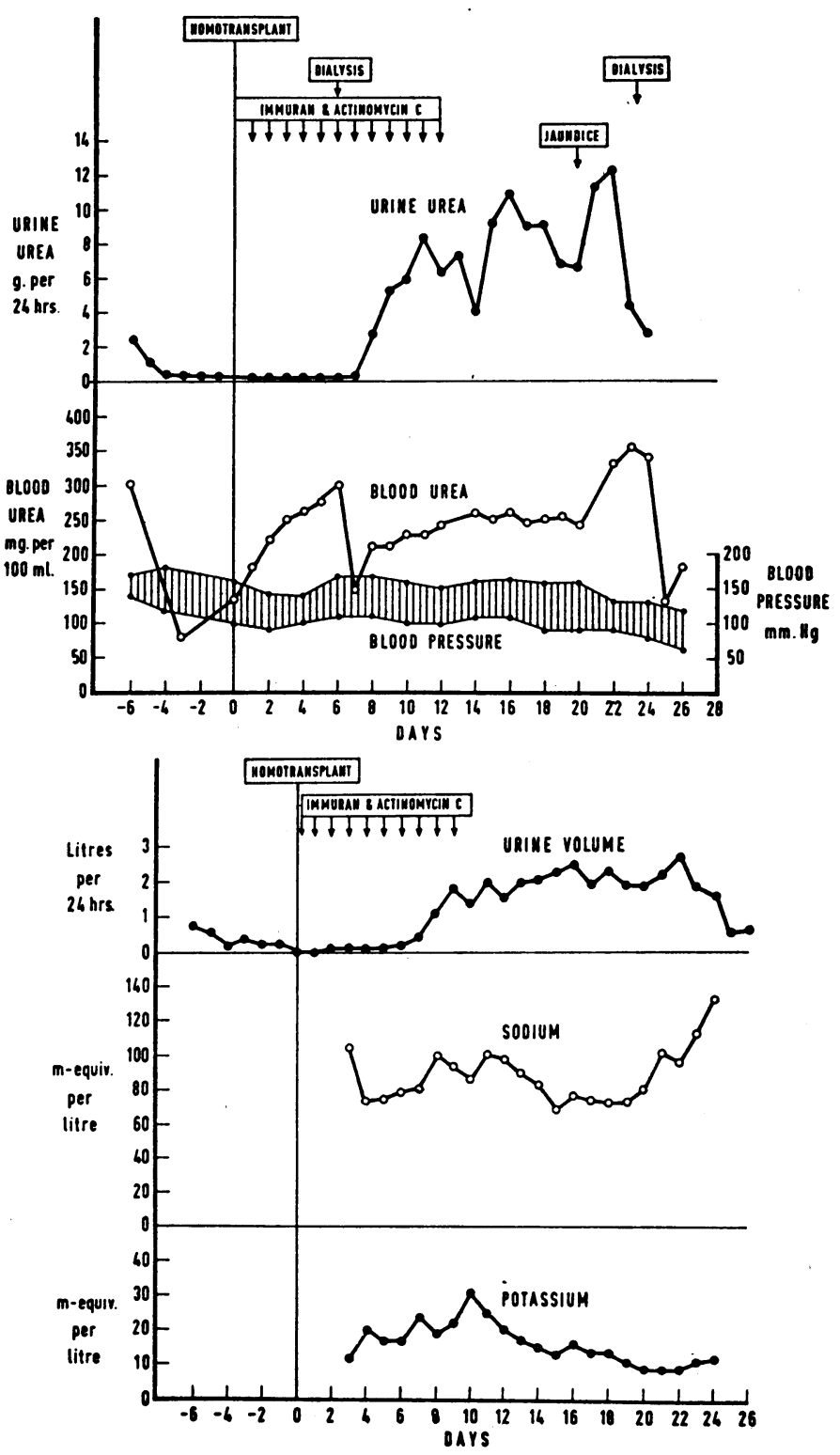

FIG. I. - The clinical course of Case 3. 
tion of vision, pallor, lethargy, and anorexia. Recently she noticed that she bruised easily and developed headaches, vomiting, and photophobia. When she was admitted to a fever hospital in a semicomatosed condition with convulsions, the blood urea was found to be $355 \mathrm{mg} . / 100 \mathrm{ml}$. and the $\mathrm{CO}_{2} 11 \mathrm{mEq} / \mathrm{l}$, and accordingly she was transferred to Hammersmith Hospital. Examination revealed anaemia (Hb 5.6 g.), papilloedema, hypertension $(160 / 100 \mathrm{~mm}$. Hg), pulmonary oedema, and left ventricular hypertrophy. The renal failure was treated by haemodialysis approximately twice a week during the six months before homotransplantation was carried out, and she required repeated blood transfusions for anaemia.

Method Used to Suppress Rejection.-Imuran (5 mg./kg./day), hydrocortisone $(100 \mathrm{mg} . /$ day $)$, and actinomycin C (100 $\mu \mathrm{g}$. once a week) were given throughout the post-operative period.

Operation (27 December 1963).- The donor kidney (cadaver) was obtained from a man aged 57 who had died suddenly from cerebral haemorrhage. It was removed and perfused at $15^{\circ} \mathrm{C}$. within 45 minutes of death and was transplanted approximately five hours after its removal. The kidney was placed in the right iliac fossa. The vascular anastomoses took 40 minutes. Splenectomy was performed.

Post-operative Course.-There was no real evidence that the transplanted kidney ever functioned and haemodialysis was performed on five occasions during the 28 days that she lived. Ps. pyocyanea septicaemia developed during the last week. Apart from fever, there was no evidence of any localized infection.

\section{Post-mortem Examination}

Necropsy Findings.-Death was due to uraemia. There was a small abscess between the pubis and the bladder on the right side. The vascular anastomoses were healthy.

Homotransplanted Kidney.-Vasculature: The main renal artery was healthy. The interlobar and arcuate arteries showed infiltration of the media by lymphocytes and plasma cells and fat phagocytes. There was a thin film of thrombus in some and also necrosis of a few smooth-muscle cells. The interlobular arteries showed the most severe damage. Only $10 \%$ appeared healthy ; the rest showed cellular infiltration and loose fibrous thickening of the intima, medial destruction, thrombusis, and aneurysmal dilatation (Special Plate, Fig. 3). A quarter of the arterioles appeared healthy; the rest were necrotic and most of them were thrombosed. Glomeruli: There were numerous small foci of infarction in the cortex. Apart from these foci the glomeruli showed fibrosis in some, collapse in others, and infarction in a minority; $14 \%$ appeared healthy. Tubules: These varied ; some appeared healthy, others were atrophic. Interstitial tissue: There was early fibrosis and patchy cell infiltration.

Summary.-This kidney showed severe arterial disease of the transplant-rejection type. It fell hardest on the interlobular vessels and was most advanced there. The glomerular and tubular changes could all be explained as the results of the ischaemia. The interstitial fibrosis always follows the oedema of homotransplanted kidneys.

\section{Case 5}

S. L., a girl aged 17 , had chronic pyelonephritis.

History.-At the age of 4 years she was admitted to hospital with pyelitis. At 8 years she was again admitted to hospital, where $a^{\circ}$ diagnosis of renal hypoplasia and chronic pyelonephritis was made. During the next few years she was readmitted on several occasions, but with sulphonamides and antibiotics she became well enough subsequently to enjoy a full life as a schoolgirl. At the age of 16 she developed malaise, exertional dyspnoea, swollen ankles, and epistaxis, and was hypertensive $(160 / 110 \mathrm{~mm}$. $\mathrm{Hg})$, anaemic (Hb $7.3 \mathrm{~g}$.), and uraemic (180 mg.). Despite treatment the blood urea soon increased to $420 \mathrm{mg}$. and she was transferred to Hammersmith Hospital in September 1962, where she was treated by repeated haemodialysis as a prelude to kidney transplantation.

Method Used to Suppress Rejection.-Total body $x$-irradiation (125 rads) was given before operation and local $x$-irradiation (200 rads) to the kidney after operation on the 4 th, 11 th, 25 th, and 36th days. Hydrocortisone (100 mg./day) was also given.

Operation (3 December 1962).- The donor of the fresh kidney was an aunt aged 42 . The kidney was placed in the right iliac fossa. Urine was excreted immediately. The period of ischaemia was 40 minutes.
Post-operative Course.-Ten litres of urine were produced in the first 24 hours and the blood urea soon fell: it was $100 \mathrm{mg}$. at the end of the first week. Her general condition improved markedly, but there was an unexplained persistent moderate fever. A slight reduction of the blood-pressure was noted during the first two weeks but there was no subsequent significant decrease of the diastolic pressure and she was given antihypertensive drugs. Good urine volumes were maintained for four weeks, but then the urine output slowly declined and the blood urea rose from 50 to $75 \mathrm{mg}$. during the fifth week. Oliguria developed at the end of the eighth week and the blood urea rose steadily and was $330 \mathrm{mg} .10$ days before she died on the 76th day. A biopsy of the kidney taken nine days before death showed necrosis of the tubules, and an arteriogram taken three days later showed a complete block in the internal iliac artery.

\section{Post-mortem Examination}

Necropsy Findings.-Apart from renal failure the only significant finding was cytomegalic inclusion disease in the lungs.

Homotransplanted Kidney.-There was thrombosis of the main renal artery with infarction of the transplanted kidney. Sections were taken at all levels of the vasculature, but owing to the infarction it was not possible to recognize necrosis; thrombosis, or cellular infiltration. However, there were a number of interlobular arteries that showed the same type of loose intimal fibrous thickening as the other cases. This must clearly have been present before the thrombosis occurred, and it is reasonable to ascribe it to the same process as occurred in other cases.

\section{Case 6}

J. S., a woman aged 27 (Case 5 described in detail by Shackman et al., 1963), suffered from chronic pyelonephritis.

History.-At the age of 22 she was noted to have hypertension, retinitis, proteinuria, and uraemia (blood urea $70 \mathrm{mg}$.). Prolonged treatment in and out of hospital failed to arrest progress of her disease and when she was transferred to Hammersmith Hospital in July 1961 for kidney transplantation the blood urea was $370 \mathrm{mg}$., though the blood-pressure was controlled at $140 / 90 \mathrm{~mm}$. Hg.

Method Used to Suppress Rejection.-Local $x$-irradiation to the transplanted kidney (200 rads) was given on the 3rd, 16th, and 28th days. Prednisone $(60 \mathrm{mg}$./day) was also given for three weeks and then gradually reduced.

Operation.-The donor of the fresh kidney was the husband aged 29. The kidney was placed in the right iliac fossa. Urine was excreted immediately. The period of ischaemia was 24 minutes.

Post-operative Course.-Good urine volumes containing 5 to 13 g. urea per litre were excreted during the first week. By the 12th day the blood urea had fallen from 225 to $42 \mathrm{mg}$. From then on, however, the urine urea concentrations declined significantly, and by the $32 \mathrm{nd}$ day the blood urea had risen to $260 \mathrm{mg}$. The daily urine volume averaged 2.7 litres during this period. A persistent unexplained fever was present and the axillary temperature reached $104.5^{\circ} \mathrm{F} .\left(40.3^{\circ}\right.$ C.) during the second, third, and four weeks. There was also some elevation of the blood-pressure $(160 / 100 \mathrm{~mm}$. $\mathrm{Hg}$ ). At the time of her discharge home on the 46th day the temperature reached $101^{\circ} \mathrm{F}$. $\left(38.3^{\circ} \mathrm{C}\right.$.) and the blood-pressure was $180 / 120 \mathrm{~mm}$. Hg. She herself, however, said she felt quite well but it was not long before her condition declined and she died 99 days after the transplantation had been performed.

\section{Post-mortem Examination}

Necropsy was performed elsewhere. The transplanted kidney only was available.

Thrombosis of the main arteries and infarction of the kidney were present. The larger arteries showed only thrombosis. Nearly all the arcuate arteries showed focal destruction of the elastic tissue, suggesting some damage before final infarction. Similar damage was seen in interlobular arteries but was more severe and was accompanied by intimal fibrosis, and many arterioles had undergone aneurysmal dilatation. The infarction of the kidney prevented any assessment of other changes, but since the arterial damage appeared to have occurred before the final thrombosis we assume that it was of a similar nature to that of the other cases. 


\section{Case 7}

I. C., a man aged 34, had calculous chronic pyelonephritis.

History.-In 1954, after an episode of haematuria, he was found to have bilateral renal calculi and calculus in the bladder: the cause was obscure and no metabolic abnormality was found. In 1955 a right renal calculus was treated by lower polar nephrectomy, the bladder stone was removed, and the calculus in the left kidney was dealt with by nephrolithotomy. Secondary haemorrhage complicated the nephrolithotomy and an emergency nephrectomy had to be carried out. He subsequently remained in good health (apart from persistent proteinuria) and was able to accept the full responsibilities of a family doctor. In 1961 he was admitted to hospital with diarrhoea, vomiting, and cramps and was found to have low serum sodium and calcium values: the blood urea was $250 \mathrm{mg}$. In May 1962 he was hypertensive $(190 / 110 \mathrm{~mm}$. Hg), anaemic (Hb $5.6 \mathrm{~g}$.), and had a bilateral papilloedema, retinal haemorrhage and exudates, and congestive cardiac failure. Some improvement followed treatment with antihypertensive drugs, blood transfusions, and calcium, but he soon relapsed and was transferred to Hammersmith Hospital, where repeated haemodialysis, blood transfusions, and major efforts to control the hypertension by drug therapy were only partially successful. The patient decided that he would not continue to submit to this regime and would submit only to renal transplantation.

Method Used to Suppress Rejection.-Total body $x$-irradiation (150 rads) was given before operation and local $x$-irradiation (200
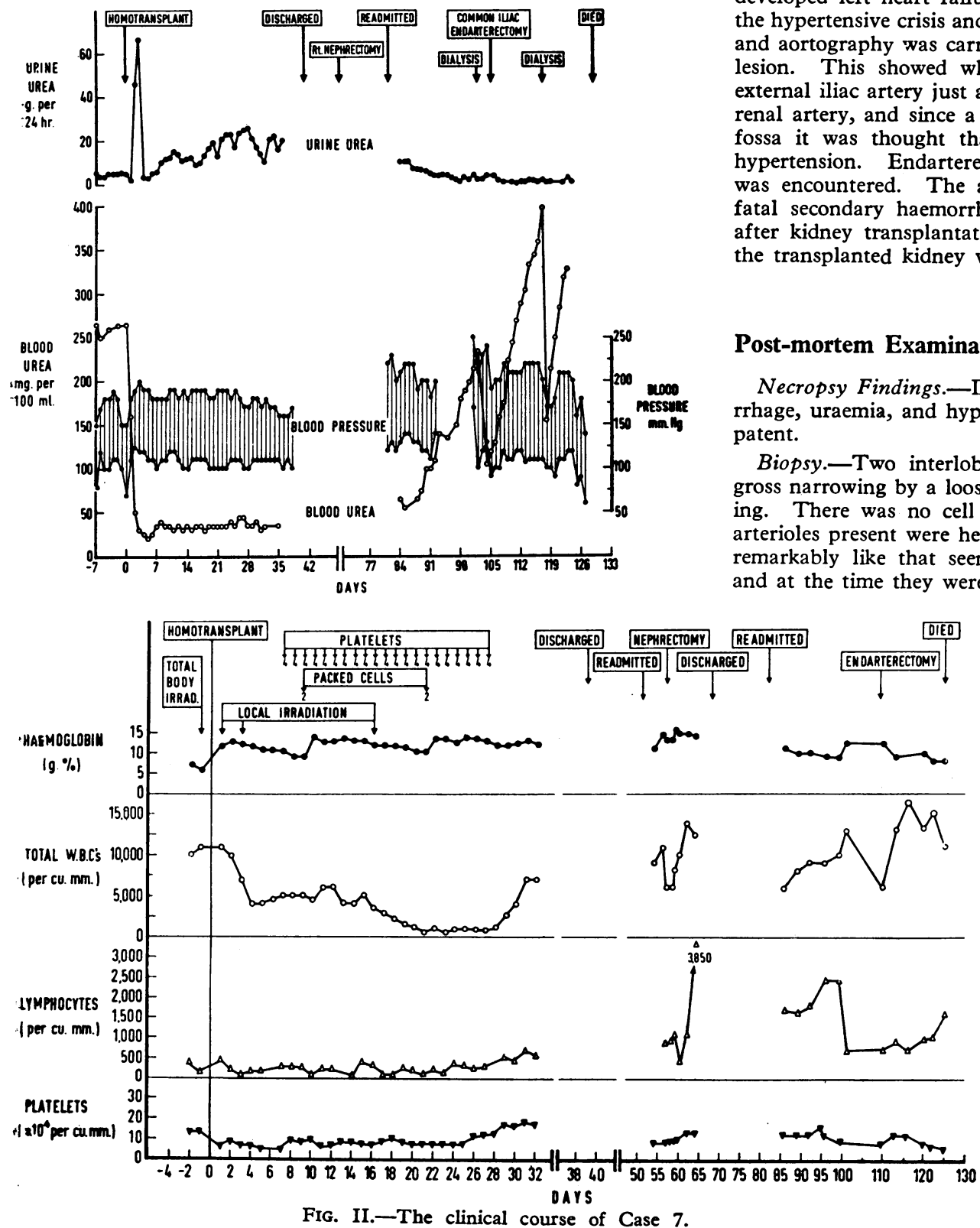

FIG. II.-The clinical course of Case 7. rads) to the kidney immediately after the operation and on the 4th and 16th days. Prednisone (60 mg./day) was also given.

Operation (13 August 1962). - The donor of the fresh kidney was an unrelated man aged 27 . The kidney was placed in the right iliac fossa. Urine was excreted after 20 minutes. The period of ischaemia was 40 minutes.

Post-operative Course.-More than 4 litres of urine, containing $14 \mathrm{~g}$. of urea per litre, were excreted during the first day, and within three days the blood urea had fallen to $30 \mathrm{mg} . / 100 \mathrm{ml}$. and stayed virtually at this level throughout the five weeks he remained in hospital (Fig. II). There was no striking change in the diastolic bloodpressure, although a slight reduction to $160 / 100 \mathrm{~mm}$. Hg gave some reason for optimism during the fifth week. His recovery was quite uneventful and he was discharged on 21 September with good renal function.

Subsequent History.-He was readmitted on 6 October with fever $\left(103^{\circ} \mathrm{F} . ; 39.4^{\circ} \mathrm{C}\right.$.), pain in the right lumbar region, and proteinuria (30 mg./100 ml.). It was assumed that his remaining kidney had recurrent infection and it was removed. His general condition improved and the proteinuria, fever, and local signs disappeared, although the hypertension persisted and was $190 / 100 \mathrm{~mm}$. $\mathrm{Hg}$ when he was discharged home 12 days later. He remained well for five weeks but then suddenly developed a hypertensive crisis $(240 / 140$ $\mathrm{mm} . \mathrm{Hg}$ ) which did not respond to sedation and large doses of antihypertensive drugs. The blood urea was $40 \mathrm{mg} . / 100 \mathrm{ml}$., but oliguria gradually developed and he became progressively uraemic and developed left heart failure and pulmonary oedema. The cause of the hypertensive crisis and progressive renal failure remained obscure, and aortography was carried out in order to exclude a local vascular lesion. This showed what appeared to be an obstruction of the external iliac artery just above the point of anastomosis to the donor renal artery, and since a loud bruit was audible over the right iliac fossa it was thought that this obstruction could account for his hypertension. Endarterectomy was performed but no obstruction was encountered. The arteriotomy wound became infected and a fatal secondary haemorrhage suddenly occurred on the 126th day after kidney transplantation. Four days before death a biopsy of the transplanted kidney was taken.

\section{Post-mortem Examination}

Necropsy Findings.-Death was due to a combination of haemorrhage, uraemia, and hypertension. The vascular anastomoses were patent.

Biopsy.-Two interlobular arteries were present. Both showed gross narrowing by a loose mucoid connective-tissue intimal thickening. There was no cell infiltration or medial necrosis, and a few arterioles present were healthy. The type of intimal thickening was remarkably like that seen in uncontrolled malignant hypertension, and at the time they were regarded as due to this cause.

Homotransplanted Kidney-Vasculature: The suture line was healthy. Just distal to this the wall of the renal artery had ruptured and there was an aneurysm, the wall of which was formed of adventitia. There was no sign of medial damage adjacent to the rupture. The interlobar arteries all showed focal medial damage with destruction of muscle fibres and tears in the elastic. A few showed intimal thickening. There were similar changes in the arcuate arteries. Among the interlobular arteries about a third had some medial destruction, usually associated with intimal fibrous thickening like that seen in the biopsy (Special Plate, Fig. 4). Another third had this type of intimal fibrosis but with an intact media. Many of the remaining third had collections of reactive cells (plasma cells, histiocytes, and lymphocytes) in their lumina. The arterioles were mostly healthy ; a few contained reactive cells and a few had medial damage. Glomeruli : Some showed slight basement-membrane thickening. 
Tubules: Some were well preserved but dilated; others were invaded by plasma cells and macrophages and were disintegrating. Interstitial tissue: This tissue was greatly increased owing to oedema and laying down of collagen. This was irregularly infiltrated by plasma cells, lymphocytes, and histiocytes.

Summary.-The long survival of this patient could account for the more fibrous and less active changes in the renal vasculature. At the time of the renal biopsy the arterial changes were attributed to malignant hypertension, but this opinion was revised when the necropsy sections showed medial damage and a spread of the lesions to arcuate and even interlobar arteries. Comparison with other cases suggested that this patient's arterial lesions were of a similar type but that they had progressed less rapidly and had reached a more sclerotic stage.

\section{Discussion}

The facts which emerge from our own series of cases and from the reports of Porter et al. (1963) and of Nemeth et al. (1963) are :

\section{Clinical Features}

(a) The time of onset of the vascular lesions varies. In our own series we have found it as early as nine days after transplantation. The latest time of onset in our series was two and a half months. Porter et al. (1963) did not encounter an onset prior to 15-19 days.

(b) An early onset of unexplained persistent fever after the operation (Nemeth et al., 1963) is ominous: of six such cases none survived longer than two months. A high fever corresponding to that which occurs in the toxic syndrome in dogs (Dempster, 1953a) was not seen (except in Case 3, and then only at a time when a septicaemia had already developed). The tense painful kidney characteristic of cellular rejection in the dog was not encountered. In this respect our experience in no way corresponds to that of Starzl et al. (1963) and Woodruff et al. (1963), who were able to reverse rejection by the administration of large doses of Imuran (azathioprine) and steroids when alarming symptoms of the toxic syndrome appeared. A symptomless development of vascular rejection has also been the experience of Küss, Legrain, Basset (personal communication, 1964). The mode of onset, therefore, must vary according to circumstances so far undefined. Our Case 7, after a period of two and a half months with normal renal function, suddenly presented with a hypertensive crisis which we have reason to believe was the result of an already established obliterative vascular disease in the transplanted kidney.

(c) Early post-operative evidence of impaired renal function occurred in Cases 1,2 , and 5 . The characteristic feature was a sudden fall in glomerular filtration followed by a slow decline in renal function.

(d) Hypertension is usually but not invariably an accompanying feature. In some cases the already existing hypertension appears to be further increased in severity as a direct result of the vascular lesion. This was very marked in Case 7.

(e) The incidence of the vascular lesion is higher than might be deduced from the report of Porter et al. (1963). This could be explained by the high incidence in their series of problems involved in transplanting cadaveric kidneys.

\section{Pathology}

The vascular lesions varied in severity and with the length of survival, and also with the size of vessel. In all our cases the interlobular arteries were the most severely affected and the largest arteries the least so. In the earliest case ( 9 days) there was an infiltration of cells beneath and apparently damaging the endothelium (Special Plate, Fig. 1). Similar cells were often present in the adventitia. Medial danage was minimal and limited to necrosis of odd muscle cells. The infiltrating cells comprised recognizable plasma cells, lymphocytes, and cells resembling histiocytes. There is circumstantial evidence that the latter are probably plasma cell precursors (see below).

In the three cases surviving 25 to 28 days there was severe and widespread vascular damage, three-quarters of the interlobular arteries being affected. In each patient individual arteries varied, but three changes occurred in varying degrees: necrosis, thrombosis, and intimal thickening. Medial necrosis was very frequent and affected part or all of the circumference ; it occurred as a loss of nuclear staining and shrinkage or disappearance of the muscle cells, often without apparent fibrinoid necrosis. Thrombosis was seen either as total occlusion of the whole lumen or as a layer of fibrin-staining material next to the media. The intimal thickening (Special Plate, Figs. 2 and 3) was usually accompanied by medial destruction ; it consisted of a loose, cellular connective tissue with scanty aniline-blue staining fibres. Sometimes this formed the whole thickening, but sometimes there were masses of fibrin-staining material next to but distinct from the media and often large fat-containing phagocytes. Infiltrating cells were not frequent and were of the same type as described above. Arterial lesions spread proximally to the arcuate arteries, but interlobar arteries were little affected. Distally, more than half the arterioles showed frank necrosis and some were aneurysmal. In all cases the cellular infiltration was sparse.

The two cases surviving 73 and 99 days both had massive infarction of the kidneys, so that only intimal fibrosis could be recognized as preceding the final thrombosis. The type of recognizable loose fibrosis suggested that these kidneys had undergone a similar type of vascular damage.

The one case surviving 126 days had much less intense lesions. Medial necrosis had been focal, affecting part of the circumference of a minority of arteries, but was now visible as scars (Special Plate, Fig. 4). The intima was thickened by loose connective tissue with scanty cells, apparently histiocytes and occasionally foam cells, and was rather more mature than at 28 days. Cellular infiltration with plasma cells was more marked than at 28 days and was frequently intramural and luminal as well as adventitial and affected the distal interlobular arteries most. The lesions spread proximally to the interlobar arteries but not distally, and the arterioles remained healthy apart from plasma cells in their lumina.

\section{Correlating Factors}

This lesion can develop in the young or middle-aged, in cases of pyelonephritis or glomerulonephritis, in recipients of fresh or preserved kidneys, in hypertensive and non-hypertensive recipients, in cases where the donor and recipient were related or quite unrelated. Close blood-grouping has no obvious advantage ; compatible groupings are essential to avoid incompatible reactions in the transplanted kidney. From a survey of publications the method of modifying the homograft reaction has no influence: (1) pre-operative sublethal total body $x$-irradiation (in a range from 100 to 400 rads, using Co bomb or linear accelerator) ; (2) pre-operative total body $x$-irradiation together with post-operative local $x$-irradiation of the kidney and even if Imuran is added (Küss et al., 1963) ; (3) Imuran and actinomycin C ; (4) Cyclophosphamide (Parsons et al., 1963). The lesion has been reported in a case not modified by any method (Hume et al., 1955). The level at which the circulating leucocytes are controlled has apparently little influence. Our earliest and severest vascular rejections occurred in those cases receiving immuno-suppressive drugs.

\section{Comparative Analysis of Rejection}

The incidence of vascular lesions in unmodified dog kidneys is about $4 \%$; the survival range was 5 to 18 days (Dempster, 1964). The incidence in dogs modified by antimetabolic drugs 
is as follows: arterial fibrinoid necrosis affected $19 \%$ of those kidneys surviving between 15 and 21 days; fibrous intimal thickening was present in $64 \%$ of those kidneys surviving over 70 days (Porter et al., 1964). A similar incidence has been found by Kountz, Laub, and Cohn (1964).

Thus this lesion is not confined to human cases, as has already been pointed out by Porter et al. (1963). The factor common to all the lesions in both human and dog is the presence of infiltrating immature plasma cells in the walls of the vessels. The migrating cells have been reported and illustrated previously (Simonsen et al., 1953 ; Dempster et al., 1957). In the present cases, besides recognizable plasma cells, there were cells resembling histiocytes but also giving a positive pyronin stain with the Unna-Pappenheim method. These cells appear to be identical with similar cells in the dog that have been shown by electron microscopy to be developing plasma cells. Recently the role of those cells in destroying intertubular capillaries has been demonstrated by the electronmicroscopic studies of Kountz et al. (1963). Similar cells have been described in human homotransplanted kidneys (Galle and de Montera, 1962, Fig. 14).

One could perhaps unify cellular and vascular rejection of human homotransplanted kidneys on the basis of the activity of circulating plasma-cell precursors. These cells appear to recognize foreign endothelium immediately on contact. In the socalled cellular rejection these plasma cells disrupt the intertubular capillaries, whereas in the vascular rejection they disrupt the endothelium of the pre-glomerular vessels. In both processes renal failure is precipitated by progressive focal ischaemia of the tubules. In the cellular rejection tubular ischaemia is the direct result of capillary disorganization (Tyler et al., 1964), whereas in vascular rejection the disruption of the endothelium allows subendothelial leakage of fibrin followed by medial necrosis, and then the progressive tissue damage leads to obliterative endarteritis and ischaemia of the parenchyma. The effects of slow focal ischaemia are very obvious in Cases 4 and 7. In Case 1 the cellular type of rejection occurred simultaneously with the early signs of a vascular lesion. The cellular rejection is probably the usual pattern of rejection in the unmodified individual, and it would follow that the main difference between cellular and vascular rejections is the speed at which vessels are damaged by migrating and differentiating plasma cells. The plasma cells in the interstitium appear to be relatively harmless, since there is no evidence that they attack tubule cells. The plasma cells which are attached to endothelial cells and which are migrating through the walls of vessels would appear to be the cells that produce the physical damage.

\section{Relation of Vascular Rejection to Naturally Occurring Kidney Diseases}

The vascular lesions found in homotransplanted kidneys differ from any natural human arterial disease. The earliest stage has a type of cell reaction and intimal damage that we have not seen before. The stage of maximal medial damage ( 25 to 28 days) bears a superficial resemblance to polyarteritis nodosa but differs both in the nature of the intimal change and in the type and paucity of cell reaction. The late lesions seen in one case are similar in some respects to those of malignant hypertension and to scleroderma, but the peculiar focal medial destruction and again the peculiar cell reaction are different.

We differ from Parsons et al. (1963) in that we do not regard these lesions as the result of malignant hypertension, for the following reasons: (1) the lesion has occurred in cases without hypertension (Küss et al., 1963); (2) the early stages of the lesion can occur within 10 days of transplantation; (3) hypertensive crises can occur after the lesion has reached the obliterative stage; (4) we believe that the lesions we have described form a pathological sequence from the earliest cellular reaction up to the late fibrosed lesion; and (5) even the late lesions differ qualitatively from anything we have seen in hypertension in non-transplanted kidneys, because they show focal medial replacement fibrosis as well as intimal thickening.

\section{Reversal of Vasular Rejection}

The effects of steroids in reversing rejection are explicable on the basis of maintenance of capillary permeability and vascular flow through the kidney (Dempster, 1953a, 1953b). A percentage of cases of periarteritis nodosa respond dramatically to steroids but a high proportion do not. Steroids are unlikely to reverse the rejection process once the obliterative lesion is well established or when the intertubular capillaries are disorganized. The reversal of the early rejection process by steroids and their subsequent failure to reverse at a later stage as reported by Porter et al. (1963), can thus be explained.

\section{Immunogenetic Theory of Rejection}

Porter et al. (1963) express the view that the current notion of the immunogenetic basis of graft rejection would lead one to expect a weak and delayed action in cases where there is a close relationship between donor and recipient. There is a report of delay in onset of vascular lesions in dizygotic twins of about 8 months, which supports the theory (Hamburger et al., 1962). Our own experience offers no positive evidence in favour of a delay in onset in closely related donor-recipient cases since our one case of brother to brother (Case 1) was rejected in nine days by a process which could not have been more severe and acute ; recent evidence supports this: “. . . 37 of 88 transplants from mother, father or siblings have failed within three months" (Murray, 1964). On the other hand, a delay in onset of two and a half months was observed in the case where donor and recipient were quite unrelated (Case 7). A number of details are still unknown about the exact relationship of the genes to rejection processes. On our present evidence, except for one brother-to-brother homotransplant which still survives more than three years (Shackman et al., 1963), there would appear to be no greater risk of rejection if the donor is unrelated. Indeed, some of the preliminary reports of heterotransplants in the human indicate that they have survived longer than several human homotransplanted kidneys (including our own brotherto-brother transplant, Case 1), and this is certainly not predictable on the present immunogenetic theory.

The feature which dominates the pathology of both canine and human homotransplanted kidncys is vascular damage by plasma-cell precursors. The parenchymal involvement appears to be secondary.

\section{Summary}

In a series of 13 consecutive cases of human kidney transplantation seven suffered vascular damage which led to renal failure. The cases have been arranged in order of duration of survival in order to illustrate the probable sequence and variety of lesions.

The vascular lesions found in these homotransplanted kidneys differ from any naturally occurring human arterial disease. The earliest stage has a type of cell reaction and intimal damage that we have not seen before. A differentiation has been made from periarteritis nodosa and scleroderma, but an immunological reaction of some sort is believed to be involved. Clinical and pathological reasons have been given which allow a differentiation from the vascular lesion of malignant hypertension.

An attempt has been made to unify the classical cellular lesion and the vascular lesion. The feature common to both lesions is damage to vascular endothelium by circulating plasmacell precursors. Parenchymal damage is secondary to vascular lesions.

The vascular lesions vary in severity and with the length of survival and also with the size of vessel. In all our cases the interlobular arteries were the most severely affected and the largest arteries the least so. 
In our experience the onset of the vascular lesion does not give rise to the alarming signs associated with cellular rejection (toxic syndrome). Accordingly we have been unable to reverse the rejection process because it has been well established by the time signs of renal failure have occurred.

In our whole series of 13 cases the longest survivals have received $x$-irradiation and the shortest survivals immunosuppressive drugs.

We are grateful to Sir Billy Butlin for a gift which has covered some of the expenses involved in this work.

ADDENDUM.- Since the paper was prepared for press another patient with kidney transplantation has died. The cause of death was haemorrhage from the arterial anastomosis on the 25 th post-operative day.

Splenectomy was performed and he was given daily $4 \mathrm{mg}$. of azathioprine (Imuran) per $\mathrm{kg}$. and $60 \mathrm{mg}$. of prednisone ; actinomycin $\mathrm{C}$ was given at intervals. The function of this kidney up until death appeared to be normal (blood urea 40 mg. $/ 100 \mathrm{ml}$.) and only persistent infection gave cause for concern. On histological examination of the kidney, however, there was definite evidence that early widespread rejection vascular disease had developed without giving rise to a rejection crisis.

The vessels of the transplanted kidney showed subendothelial cellular infiltration and focal medial necrosis. The lesions affected interlobar, arcuate, and interlobular arteries and afferent arterioles about equally. Our earlier statement that the interlobulars are always most severely affected needs revising. There was also focal destruction of small groups of tubules apparently by a process of cellular rejection. This is the second case in our series which shows signs of both cellular and vascular types of rejection. The severity of the vascular lesions was a little greater than that of Case 1 (J.F.), but was less than the other three cases surviving for 20-30 days.

\section{REFERENCES}

Dempster, W. J. (1953a). Acta med. scand., 144, 360.

(1953b). Arch. int. Pharmacodyn., 95, 253.

(1957). An Introduction to Experimental Surgical Studies. Blackwell, Oxford.

(1964). In preparation.

Galle, P., and Montera, H. de (1962). Rev. franç. Etud. clin. biol., 7, 40 .

Goodwin, W. E., Kaufman, J. J., Mims, M. M., Turner, R. D., Glassock, R., Goldman, R., and Maxwell, M. M. (1963). Y. Urol., 89, 13.

Hamburger, J., Vaysse, J., Crosnier, J., Auvert, J., Lalanne, C. M., and Hopper, J. (1962). Amer. f. Med., 32, 854 .

Hopper, J. Tubiana, M., Lalanne, C. M., Antoine, B., Auvert, J., Soulier, J. P., Dormont, J., Salmon, C., Maisonnet, M., and Amiel, J. L. (1959). Presse méd., 67, 1771.

Hume, D. M., Merrill, J. P., Miller, B. F., and Thorn, G. W. (1955). f. clin. Invest., 34, 327 .

Kountz, S. L., Williams, M. A., Williams, P. L., Kapros, C., and Dempster, 'W. J. (1963). Nature (Lond.), 199, 257.

K. Laub, D. R., and Cohn, R. (1964). F. Amer. med. Ass. In press.

üss, R., Legrain, M., Mathé, G., Nedey, R., and Camey, M. (1962). Rev. franç. Etud. clin. biol., 7, 1048.

Merrill

Merrill J. P., Murray, J. E., Harrison, J. H., Friedman, E. A., Dealy, J. B., and Dammin, G. J. (1960). New Engl. f. Med., 262, 1251. - Takacs, F. J., Hager, E. B., Wilson, R. E., and Dammin, G. J. (1963). F. Amer. med. Ass., 185, 347.

Michon, L., Hamburger, J., Oeconomos, N., Delinotte, P., Richet, G., Vaysse, J., and Antoine, B. (1953). Presse méd., 61, 1419.

Murray, J. E. (1964). Transplantation, 2, 147.

- Merrill, J. P., Harrison, J. H., Wilson, R. E., and Dammin, G. J. (1963). New Engl. 7. Med., 268, 1315 .

Nemeth, A., Petri, G., Gal, G. Y., Fazekas, S., Altorjay, T., Scultety, S., Balogh, E., and Karpati, F. (1963). Orv. hetil., 104, 2017.

Parsons, F. M., Markland, C., Raper, F. P., and Fox, M. (1963). Brit. med. F., 1, 930.

Porter, K. A., Thomson, W. B., Owen, K., Kenyon, J. R., Mowbray, J. F., and Peart, W. S. (1963). Ibid., 2, 639.

- Peart, W. S., Kenyon, J. R., Joseph, N. H., Hoehn, R. J., and Calne, R. Y. (1964). N. Y. Acad. Sci. In press.

Shackman, R., Dempster, W. J., and Wrong, O. M. (1963). Brit. F. Urol., 35, 222.

Simonsen, M., Buemann, J., Gammeltoft, A., Jensen, F., and Jørgensen, K. (1953). Acta path. microbiol. scand., 32, 1.

Starzl, T. E., Marchioro, T. L., and Waddell, W. R. (1963). Surg. Gynec. Obstet., 117, 385.

Tyler, H. M., Williams, M. A., and Dempster, W. J. (1964). Nature (Lond.), 201, 84.

Woodruff, M. F. A., Robson, J. S., Nolan, B., Lambie, A. T., Wilson, T. I., and Clark, J. G. (1963). Lancet, 2, 675.

\title{
Study of Renal Vessels by Microdissection in Human Transplantation*
}

\author{
E. M. DARMADY, $\dagger$ M.D., F.R.C.P., F.C.PATH. ; J. M. OFFER, $\dagger$ B.SC. ; FAY STRANACK, $\dagger$ PH.D.
}

[With Special Plate]

Brit. med. F., 1964, 2, 976-978

Renal changes following transplantation would seem to fall into two groups: those which follow closely upon transplantation (5-19 days) and those which survive initial stages and subsequently develop vascular changes.

The histological appearances have been fully described elsewhere (Dempster, 1953 ; Hume et al., 1955 ; Darmady et al., 1955 ; Küss et al., 1962 ; Hamburger et al., 1963 ; Murray et al., 1962, 1963 ; Porter et al., 1963 ; Calne et al., 1963). In the first group the outstanding changes have been necrosis of the tubular epithelium of the first part of the proximal convoluted tubules, and later spreading to the remainder of the tubule. At the same time there appears a patchy round-cell infiltration consisting of lymphocytes, histiocytes, and plasma cells with pyronin-positive material in the cytoplasm, and, in the second

* Based on a lecture given by invitation at a Symposium on Renal Transplantation at the British Postgraduate Medical School, London, 26 April 1963.

†From Portsmouth and Isle of Wight Area Pathological Service. group, proliferation of the vascular intima, degeneration of media, and aneurysmal dilatation with interstitial fibrosis and tubular atrophy.

In this communication we propose to demonstrate by microdissection the extent of these changes and to suggest that vascular lesions which may be observed in the kidney after transplantation occur earlier and more often than previously thought.

\section{Method and Material}

The kidneys were fixed in $10 \%$ neutral formol-saline, and portions of kidney were submitted to us for microdissection. These were prepared by the methods previously described (Darmady and Stranack, 1957). For microdissection of the vessels the length of maceration-time was reduced to 47 hours as opposed to 48 hours. 
W. J. DEMPSTER ET AL.: REJECTION PROCESSES IN HUMAN HOMOTRANSPLANTED KIDNEYS

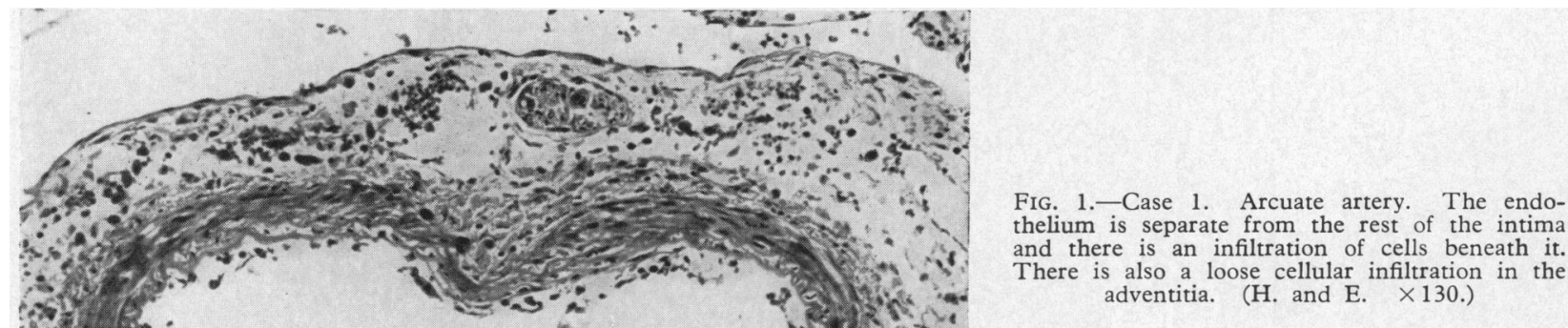

FIG. 2.-Case 3. Interlobular artery. The intima is greatly thickened by loose connective tissue containing a few foamy phagocytes and a little fibrin (extreme right). The media is destroyed. Cellular infiltration is sparse. (H. and E. 145.)

thelium is separate from the rest of the intima

There is also a loose cellular infiltration in the करती ate

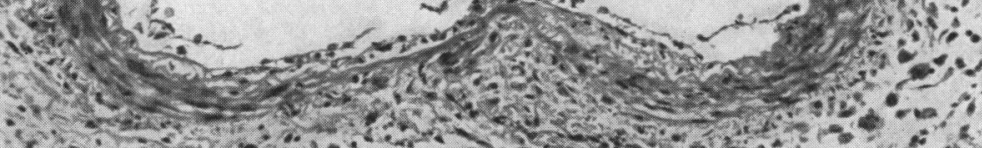

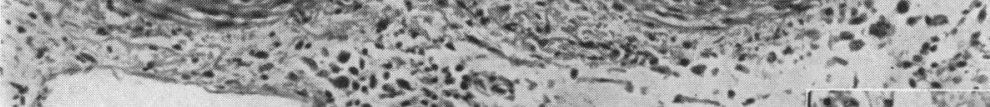

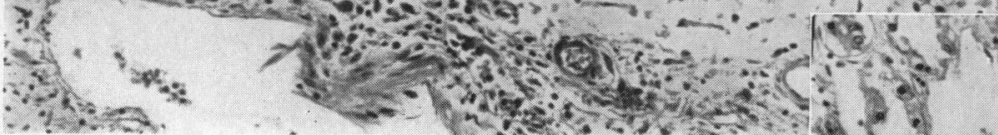
dventitia. (H. and E. $\times 130$.)
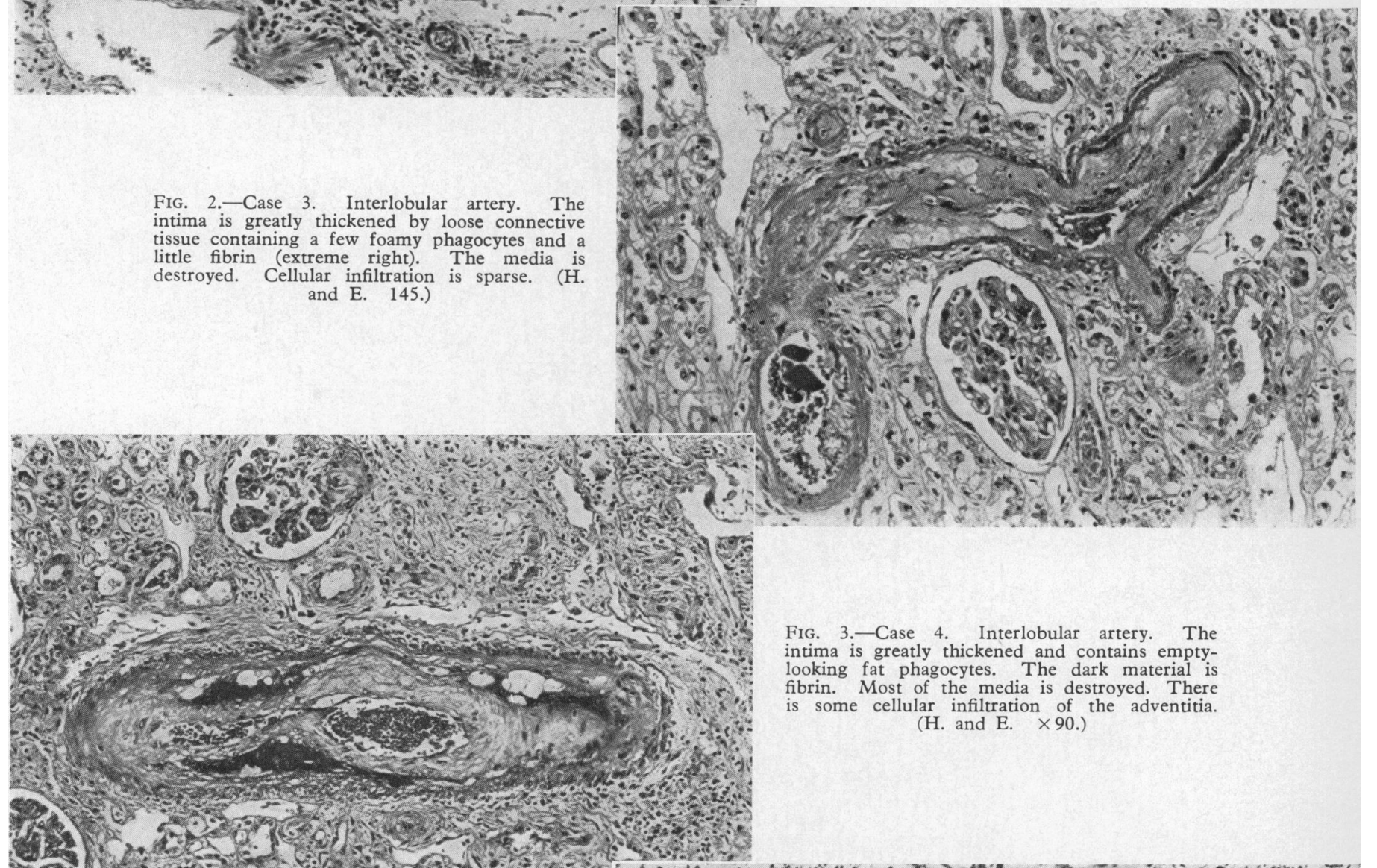

FIG. 4.-Case 7. Interlobular artery, oblique section. The intima is greatly thickened. The media is preserved at the left-hand end but destroyed in the middle. Fibrin is present near the lumen on the right and there is some cellular infiltration in this area. Note the intertubular oedema and paucity of cell infiltration

Fig. 3.-Case 4. Interlobular artery. The intima is greatly thickened and contains emptylooking fat phagocytes. The dark material is is some cellular infiltration of the adventitia.

$$
(\mathrm{H} \text {. and } \mathrm{E} \text {. } \times 90 \text {.) }
$$
here. $(\mathrm{H}$. and $\mathrm{E} . \times 90$.)

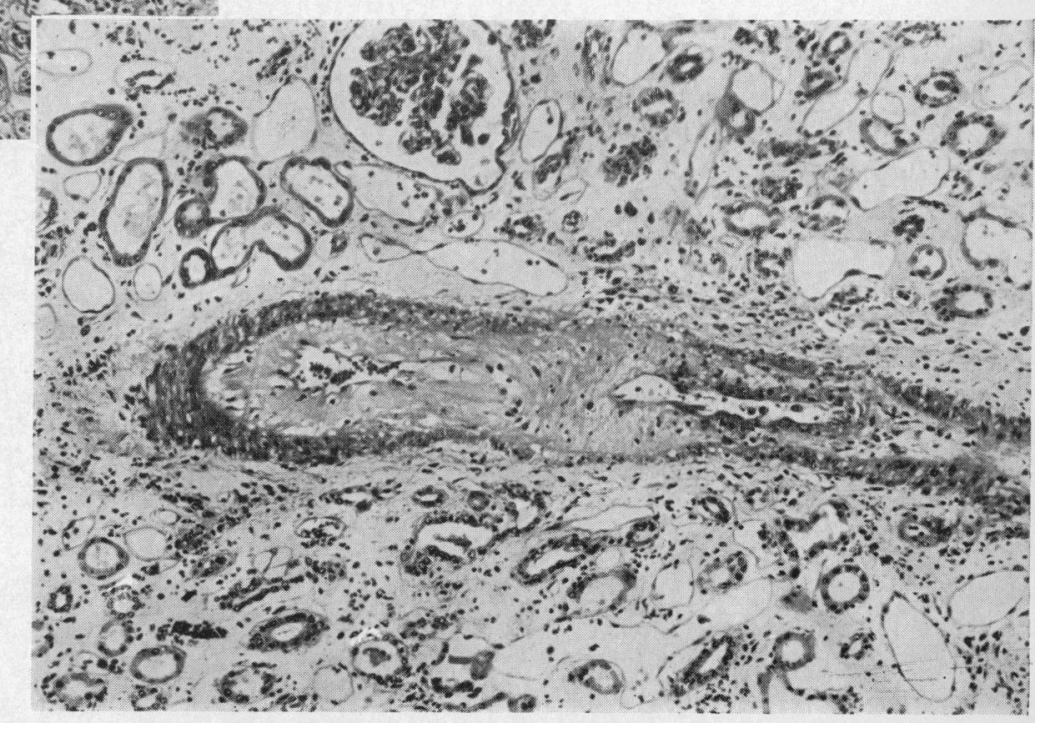

